\title{
LIMITATIONS IN CYTODIAGNOSIS- AN INSTITUTIONAL STUDY
}

Prasad Uma ${ }^{1}$, K. Rajani ${ }^{2}$

${ }^{1}$ Associate Professor, Department of Pathology, Andhra Medical College, Vishakapatnam, Andhra Pradesh.

${ }^{2}$ Assistant Professor, Department of Pathology, RIMS Medical College, Srikakulam, Andhra Pradesh.

\section{ABSTRACT}

\section{BACKGROUND}

Fine needle aspiration cytology has replaced open biopsy in majority of the palpable lesions. Differentiation between benign and malignant lesions is possible with this procedure with low cost, but has certain limitations. In the present study, the limitations of cytodiagnosis in various palpable lesions in the body is analysed.

The aim of the study was to know the prevalence of various lesions which could be diagnosed on cytology, its limitations and need for histopathological examination.

\section{MATERIALS AND METHODS}

A prospective observational study was conducted in the Department of Pathology at tertiary care centre in rural area. 1200 cases attending for fine needle aspiration for a period of 2 years from January 2014 to December 2015 was taken up for the study. After obtaining informed consent from the patients, fine needle aspiration was performed using a 22 - 24 gauge needle with $10 \mathrm{~mL}$ syringe and long lumbar puncture needle for guided aspirations. Smears were fixed in 95\% isopropyl alcohol and stained with Haematoxylin and Eosin. Air dried smears were stained with May-Grunwald stain and special stains were done wherever necessary. The tissue was subjected for histopathological examination wherever indicated and results tabulated. Overall diagn ostic accuracy, sensitivity and specificity of cytology as a diagnostic procedure was calculated.

\section{RESULTS}

The overall accuracy of diagnosing granulomatous lymphadenitis and lymphoproliferative disorders on cytology was $65.71 \%$. The overall accuracy of diagnosing fibrocystic disease of breast proliferative type was $80 \%$ and ductal carcinoma of breast was $100 \%$ on cytology. The overall accuracy of diagnosing follicular adenoma of thyroid was $36.20 \%$ and malignancy was $100 \%$ on cytology. The overall accuracy of diagnosing both benign and malignant lesions of salivary gland was $100 \%$ on cytology. The overall accuracy of diagnosing soft tissue tumours was $88.67 \%$ on cytology. In lesions of bone, skin and ultrasonographic-guided lesions of abdomen, the overall accuracy was $100 \%$. On Pap smears, the overall accuracy was $84.48 \%$.

\section{CONCLUSION}

In cases of granulomatous lymphadenitis without significant necrosis and negative AFB, fibrocystic disease of breast, follicular adenoma of thyroid, vascular tumours, soft tissue tumours with nuclear atypia and cases of atypical squamous cell of undetermined significance and high-grade intraepithelial lesions on Pap smears need histopathological examination for accurate diagnosis.

\section{KEYWORDS}

Cytodiagnosis, Limitations, Overall Accuracy, Various Lesions.

HOW TO CITE THIS ARTICLE: Uma P, Rajani K. Limitations in cytodiagnosis- an institutional study. J. Evolution Med. Dent. Sci. 2018;7(04):479-486, DOI: $10.14260 /$ jemds/2018/107

\section{BACKGROUND}

Many of the clinicians feel that fine needle aspiration cytology (FNAC) remains the most important contribution of the technique from a practice point of view. It helps in differentiating benign and malignant lesions and offers specific diagnosis in inoperable cases as a guide to rational treatment. Although, the use of FNAC has widened, there are pressures for specialisation in this discipline with limitations.[1] The fundamental requirements on which the success of FNAC depends are representativeness and adequacy of the sample. Haematoma, infarction, capsule

'Financial or Other Competing Interest': None.

Submission 05-11-2017, Peer Review 06-01-2018,

Acceptance 13-01-2018, Published 22-01-2018.

Corresponding Author:

Prasad Uma,

Q No.49-3-3, Lalithanagar,

Visakhapatnam-530016,

Andhra Pradesh.

E-mail: usha1966411@gmail.com

DOI: $10.14260 /$ jemds $/ 2018 / 107$ pseudoinvasion and pseudomalignant reparative reactions cause real diagnostic difficulties.[2] The aims and objective of the study was to know the prevalence of various lesions, which could be diagnosed on cytology, limitations of cytodiagnosis in various lesions of lymph node, breast, thyroid, soft tissue, bone, salivary glands, skin, pap smears, ultrasonographic-guided intraabdominal aspirations and the need for histopathological examination.

\section{MATERIALS AND METHODS}

A prospective observational study was conducted in the Department of Pathology at a tertiary care centre in rural area. 1200 cases attending for fine needle aspiration in the rural hospital for 2 years from January 2014 to December 2015 was taken up for the study. After obtaining informed consent from the patients, fine needle aspiration was performed using a 22 - 24 gauge needle with $10 \mathrm{~mL}$ syringe and a long lumbar puncture needle for guided aspirations. Smears were fixed in 95\% Isopropyl alcohol and stained with Haematoxylin and Eosin. Air dried smears were stained with May-Grunwald stain and special stains for acid fast bacilli and 
fungus were done wherever necessary. Aspirations from lymph node, breast, thyroid, soft tissue, bone and joints, salivary glands, skin, Pap smears and ultrasonographicguided intraabdominal lesions were analysed. The tissue was subjected for histopathological examination wherever indicated and results tabulated.

\section{Statistical Methods}

To calculate overall diagnostic accuracy, sensitivity and specificity of cytology as a diagnostic procedure taking histopathology as a gold standard.

\section{RESULTS}

A total of 1200 aspirates during this period were analysed. Lymph node aspirates were $30.83 \% \quad(n=370)$, breast aspirates were $12.91 \%(\mathrm{n}=155)$, thyroid aspirates were $20.08 \%(n=241)$, soft tissue aspirates were $8.83 \%(n=106)$, salivary gland aspirates were $2.08 \%(n=25)$, bone and joint lesions were $1.41 \%(\mathrm{n}=17)$, skin aspirates were $2.08 \%$ $(\mathrm{n}=25)$. USG-guided aspirates from intraabdominal lesions were $3.08 \%(n=37)$ and Pap smears were 9.66\% $(n=116)$.

\section{Lymph Node Lesions}

Non-specific lymphadenitis and tuberculous lymphadenitis were the common lesions and on follow-up responded very well to antibiotics. In all the cases of metastatic lymph nodes, the primary tumour could be detected and treated appropriately [Table 1].

19 cases of granulomatous lymphadenitis without necrosis and negative for acid fast bacilli and 16 cases of lymphoproliferative disease were subjected for histopathological examination as they needed definitive diagnosis.

In 19 cases of granulomatous lymphadenitis on cytology: 7 cases were tuberculous lymphadenitis, 5 cases were fungal granulomas, 5 were Hodgkin's lymphoma and 2 cases were squamous cell carcinomatous deposits on histopathology.

In 16 cases of lymphoproliferative disorders on cytology: 11 were Non-Hodgkin's Lymphoma, 3 were non-specific lymphadenitis and 2 were Kikuchi's lymphadenitis on histopathology [Table 2]. Sensitivity, specificity and overall diagnostic accuracy of cytology in diagnosing lymph node lesions were $47.82 \%, 58.33 \%$ and $65.71 \%$ respectively.

\section{Breast Lesions}

The commonest lesion on cytology was fibroadenosis (20.64\%) followed by fibroadenoma (19.35\%). Ductal carcinoma constituted $9.67 \%$ of cases and gynaecomastia in $7.74 \%$ of cases. Fibrocystic disease of proliferative type was $6.45 \%$ and atypical ductal hyperplasia in $9.67 \%$ of cases [Table 3].

There was $100 \%$ cytohistopathological correlation in cases of fibroadenoma of breast, ductal carcinoma and gynaecomastia. Fibrocystic disease of proliferative type showed $80 \%$ correlation, 2 cases showed atypical ductal hyperplasia on histopathology. In phyllodes tumour, 9 cases were benign phyllodes and 4 cases were of intermediate grade. In $73.33 \%$ cases of atypical ductal hyperplasia correlated on histopathology and 4 cases showed features of epithelial hyperplasia [Table 4]. Sensitivity, specificity and overall diagnostic accuracy of breast lesions were 100\%, $100 \%$ and $89.47 \%$ respectively.

\section{Thyroid Lesions}

Nodular goitre constituted $34.85 \%$ of cases, Hashimoto's thyroiditis (28.63\%) and follicular neoplasm (24.06\%) of cases [Table 5].

In malignant lesions, there was $100 \%$ cytohistopathological correlation. The correlation percentage in cases of nodular goitre was $94 \%, 5$ cases turned out to be papillary carcinoma on histopathology. The correlation percentage was $36.20 \%$ in follicular neoplasm. Out of 58 cases, 21 cases were diagnosed as follicular adenoma and 32 were adenomatoid goitre and 5 cases of follicular variant of papillary carcinoma [Table 6]. Sensitivity, specificity and overall diagnostic accuracy of cytology in thyroid lesions is $50 \%, 100 \%$ and $75.58 \%$ respectively.

\section{Salivary Gland Lesions}

The common lesions in salivary gland aspirations were sialadenitis (32\%), pleomorphic adenoma (32\%) and adenoid cystic carcinoma (24\%) [Table 7].

In cases of pleomorphic adenoma, the correlation percentage was $75 \%, 2$ cases showed features of carcinoma ex-pleomorphic adenoma on histopathology [Table 8].

Sensitivity, specificity and overall diagnostic accuracy of salivary gland lesions were $81.81 \%, 100 \%$ and $88.23 \%$ respectively.

\section{Soft Tissue Lesions}

Lipoma (63.20\%) were the common lesions in soft tissue aspirates followed by neurofibroma (11.32\%) [Table 9].

In ten cases of vascular tumours on cytology, 4 cases were haematoma on histopathology. Out of ten cases with diagnosis of benign spindle cell tumour, 2 cases showed intermediate grade lesion- dermatofibrosarcoma protuberans. Four cases with diagnosis of lipoma on cytology, 2 were atypical lipoma and 2 were liposarcoma. Two cases with diagnosis of neurofibroma on cytology were diagnosed as low-grade malignant peripheral nerve sheath tumour on histopathology [Table 10].

Sensitivity, specificity and overall diagnostic accuracy of soft tissue lesions are $46.66 \%, 100 \%$ and $88.67 \%$ respectively.

\section{Bone and Joint Lesions}

The common lesions in aspirates from bone and joint were ganglion $(58.82 \%)$ followed by $29.41 \%$ cases of giant cell tumour of bone [Table 11].

Sensitivity, specificity and overall diagnostic accuracy of cytology in bone and joint lesions were 100\%, 100\% and $86.66 \%$ respectively [Table 12 ].

\section{Skin Lesions, USG-Guided Intraabdominal Lesions and Pap Smears}

Keratinous cysts were the commonest skin lesions. Sensitivity, specificity and overall diagnostic accuracy of cytology in skin lesions were 100\% [Table 13, 14].

In USG-guided intraabdominal lesions, majority of the aspirates were from liver. Received biopsy only on malignant lesions. Sensitivity, specificity and overall diagnostic accuracy of cytology in USG-guided lesions were 100\% [Table 15].

In 20 cases of Atypical squamous cell of undetermined significance (ASCUS) on Pap smears, 12 cases were chronic non-specific cervicitis with metaplastic change and 8 cases 
were mild dysplasia on histopathology. In 25 cases with low grade squamous intraepithelial lesion (LSIL) on cytology $80 \%$ correlated with histopathology, but 5 cases turned out to be non-specific cervicitis on histopathology. In 18 cases with high-grade squamous intraepithelial lesion (HSIL), 8 cases showed severe dysplasia and 10 cases showed squamous cell carcinoma on histopathology. Sensitivity, specificity and overall diagnostic accuracy of cytology in Pap smears were 92.68\%, 93.33\% and $84.48 \%$ [Table 16].

\begin{tabular}{|c|c|c|}
\hline Lesions & No. of Cases & Percentage \\
\hline Non-specific lymphadenitis & 188 & 50.81 \\
\hline Tuberculous lymphadenitis & 116 & 31.35 \\
\hline Granulomatous lymphadenitis & 19 & 5.13 \\
\hline Metastatic lymph nodes & 31 & 8.39 \\
\hline Lymphoproliferative disease & 16 & 4.32 \\
\hline Total & 370 & 100 \\
\hline
\end{tabular}

\begin{tabular}{|c|c|c|c|c|}
\hline 号 & 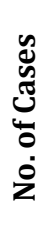 & 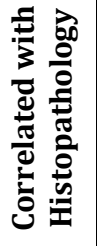 & 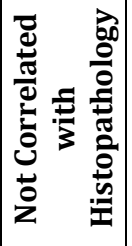 & 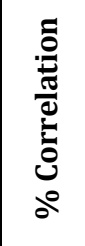 \\
\hline Granulomatous lymphadenitis & 19 & 12 & 7 & 63.15 \\
\hline Lymphoproliferative disorder & 16 & 11 & 5 & 68.75 \\
\hline Total & 35 & 23 & 12 & \\
\hline
\end{tabular}

\begin{tabular}{|c|c|c|}
\hline Lesions & No. of Cases & Percentage \\
\hline Chronic mastitis & 19 & 12.29 \\
\hline Fibroadenoma & 30 & 19.35 \\
\hline Fibroadenosis & 32 & 20.64 \\
\hline $\begin{array}{c}\text { Fibrocystic disease of non- } \\
\text { proliferative type }\end{array}$ & 9 & 5.8 \\
\hline $\begin{array}{c}\text { Fibrocystic disease of } \\
\text { proliferative type }\end{array}$ & 10 & 6.45 \\
\hline Phyllodes tumour & 13 & 8.38 \\
\hline Atypical ductal hyperplasia & 15 & 9.67 \\
\hline Ductal cell carcinoma & 15 & 9.67 \\
\hline Gynaecomastia & 12 & 7.74 \\
\hline Total & $\mathbf{1 5 5}$ & $\mathbf{1 0 0}$ \\
\hline Table 3. Cytodiagnosis in Breast Lesions- 155 \\
\hline \multicolumn{2}{|c}{}
\end{tabular}

\begin{tabular}{|c|c|c|c|c|}
\hline 包 & 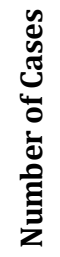 & 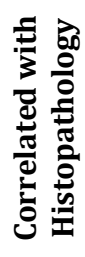 & 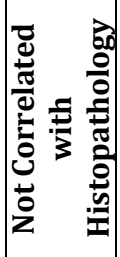 & 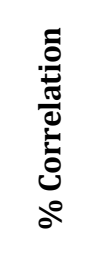 \\
\hline Fibroadenoma & 30 & 30 & - & 100 \\
\hline $\begin{array}{l}\text { Fibrocystic disease of } \\
\text { proliferative type }\end{array}$ & 10 & 8 & 2 & 80 \\
\hline Phyllodes tumour & 13 & 9 & 4 & 69.23 \\
\hline Atypical ductal hyperplasia & 15 & 11 & 4 & 73.33 \\
\hline Ductal carcinoma & 15 & 15 & - & 100 \\
\hline Gynaecomastia & 12 & 12 & - & 100 \\
\hline Total & 95 & 85 & 10 & \\
\hline \multicolumn{5}{|c|}{$\begin{array}{l}\text { Table 4. Cytohistopathological Correlation in Breast } \\
\text { Lesions- } 95\end{array}$} \\
\hline
\end{tabular}

\begin{tabular}{|c|c|c|}
\hline Lesions & No. of Cases & Percentage \\
\hline Nodular goitre & 84 & 34.85 \\
\hline Colloid cyst & 10 & 4.14 \\
\hline Hashimoto's thyroiditis & 69 & 28.63 \\
\hline Thyroglossal cyst & 5 & 2.07 \\
\hline Follicular neoplasm & 58 & 24.06 \\
\hline Hurthle cell neoplasm & 5 & 2.07 \\
\hline Papillary carcinoma thyroid & 8 & 3.31 \\
\hline Medullary carcinoma thyroid & 2 & 0.82 \\
\hline Total & $\mathbf{2 4 1}$ & $\mathbf{1 0 0}$ \\
\hline Table 5. Cytodiagnosis in Thyroid Lesions- $\mathbf{2 4 1}$ \\
\hline
\end{tabular}

\begin{tabular}{|c|c|c|c|c|}
\hline 号 & 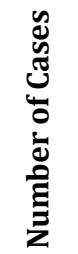 & 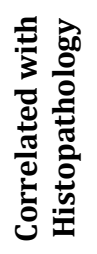 & 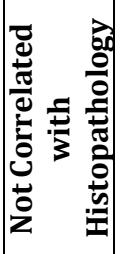 & 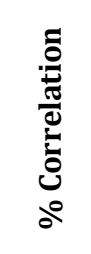 \\
\hline Nodular goitre & 84 & 79 & 5 & 94 \\
\hline Colloid goitre & 10 & 10 & - & 100 \\
\hline Thyroglossal cyst & 5 & 5 & - & 100 \\
\hline Follicular neoplasm & 58 & 21 & 37 & 36.20 \\
\hline Hurthle cell neoplasm & 5 & 5 & - & 100 \\
\hline Papillary carcinoma thyroid & 8 & 8 & - & 100 \\
\hline Medullary carcinoma thyroid & 2 & 2 & - & 100 \\
\hline Total & 172 & 130 & 42 & \\
\hline \multicolumn{5}{|c|}{$\begin{array}{l}\text { Table 6. Cytohistopathological Correlation } \\
\text { in Lesions of Thyroid- } 172\end{array}$} \\
\hline
\end{tabular}

\begin{tabular}{|c|c|c|}
\hline Lesions & No. of Cases & Percentage \\
\hline Sialadenitis & 8 & 32 \\
\hline Pleomorphic adenoma & 8 & 32 \\
\hline Mucoepidermoid carcinoma & 3 & 12 \\
\hline Adenoid cystic carcinoma & 6 & 24 \\
\hline Total & 25 & 100 \\
\hline
\end{tabular}

\begin{tabular}{|c|c|c|c|c|}
\hline 氙 & 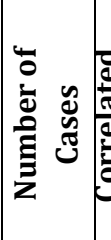 & 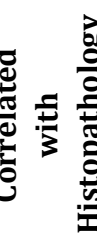 & $\begin{array}{lll} & & \\
0\end{array}$ & 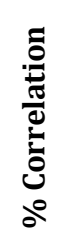 \\
\hline Pleomorphic adenoma & 8 & 6 & 2 & 75 \\
\hline Mucoepidermoid carcinoma & 3 & 3 & - & 100 \\
\hline Adenoid cystic carcinoma & 6 & 6 & - & 100 \\
\hline Total & 17 & & 2 & \\
\hline \multicolumn{5}{|c|}{$\begin{array}{c}\text { Table 8. Cytohistopathological Correlation in Salivary } \\
\text { Gland Lesions- } 17\end{array}$} \\
\hline
\end{tabular}

\begin{tabular}{|c|c|c|}
\hline Lesions & No. of Lesions & Percentage \\
\hline Vascular tumours & 10 & 9.4 \\
\hline Benign spindle cell tumours & 10 & 9.4 \\
\hline Lipoma & 67 & 63.20 \\
\hline Neurofibroma & 12 & 11.32 \\
\hline Round cell sarcoma & 4 & 3.77 \\
\hline Leiomyosarcoma & 2 & 1.88 \\
\hline $\begin{array}{c}\text { Extramedullary } \\
\text { plasmacytoma }\end{array}$ & 1 & 0.94 \\
\hline Total & 106 & 100 \\
\hline
\end{tabular}




\begin{tabular}{|c|c|c|c|c|}
\hline$\stackrel{\mathscr{0}}{0}$ & 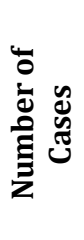 & 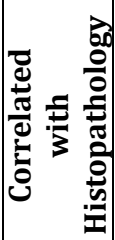 & 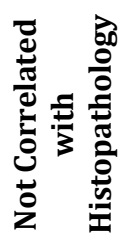 & 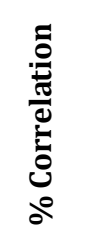 \\
\hline Vascular tumours & 10 & 6 & 4 & 60 \\
\hline Benign spindle cell tumours & 10 & 8 & 2 & 80 \\
\hline Lipoma & 67 & 63 & 4 & 94.02 \\
\hline Neurofibroma & 12 & 10 & 2 & 83.33 \\
\hline Round cell sarcoma & 4 & 4 & - & 100 \\
\hline Leiomyosarcoma & 2 & 2 & - & 100 \\
\hline $\begin{array}{l}\text { Extramedullary } \\
\text { plasmacytoma }\end{array}$ & 1 & 1 & - & 100 \\
\hline Total & 106 & 94 & 12 & \\
\hline
\end{tabular}

\begin{tabular}{|c|c|c|}
\hline Lesions & No. of Cases & Percentage \\
\hline Ganglion & 10 & 58.82 \\
\hline Giant cell tumour & 5 & 29.41 \\
\hline Metastasis & 2 & 11.76 \\
\hline Total & 17 & 100 \\
\hline
\end{tabular}

\begin{tabular}{|c|c|c|c|c|}
\hline 氙 & 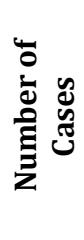 & 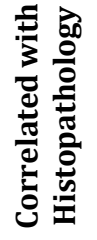 & 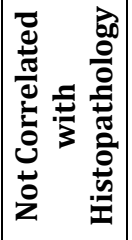 & 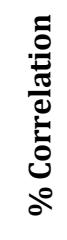 \\
\hline Ganglion & 10 & 8 & 2 & 80 \\
\hline Giant cell tumour of bone & 5 & 5 & - & 100 \\
\hline Total & 15 & 13 & 2 & \\
\hline $\begin{array}{r}\text { Table 12. Cytohistopat } \\
\text { and Jo }\end{array}$ & $\begin{array}{l}\text { logi } \\
\text { Les }\end{array}$ & $\begin{array}{l}\text { Corre } \\
s-15\end{array}$ & & \\
\hline
\end{tabular}

\begin{tabular}{|c|c|c|}
\hline Lesions & No. of Lesions & Percentage \\
\hline Keratinous cysts & 11 & 44 \\
\hline Cold abscess & 8 & 40 \\
\hline Lepromatous leprosy & 2 & 8 \\
\hline Skin metastasis & 1 & 4 \\
\hline Benign adnexal tumours & 3 & 12 \\
\hline Total & 25 & 100 \\
\hline \multicolumn{3}{|c|}{ Table 13. Cytodiagnosis of Skin Lesions- 25} \\
\hline
\end{tabular}

\begin{tabular}{|c|c|c|c|c|}
\hline 氙 & 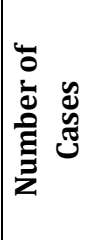 & 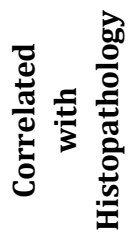 & 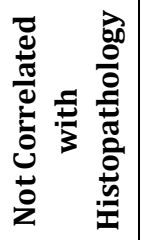 & 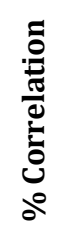 \\
\hline Keratinous cysts & 11 & 11 & - & 100 \\
\hline Skin metastasis & 1 & 1 & - & 100 \\
\hline Lepromatous leprosy & 2 & 2 & - & 100 \\
\hline Benign adnexal tumours & 3 & 3 & - & 100 \\
\hline Total & 17 & 17 & - & \\
\hline \multicolumn{5}{|c|}{$\begin{array}{l}\text { Table 14. Cytohistopathological Correlation } \\
\text { of Skin Lesions- } 17\end{array}$} \\
\hline
\end{tabular}

\begin{tabular}{|c|c|c|}
\hline Lesions & $\begin{array}{c}\text { No. of } \\
\text { Lesions }\end{array}$ & Percentage \\
\hline Liver & & \\
Hepatocellular carcinoma & 4 & 12.90 \\
Adenocarcinoma metastasis & 7 & 22.58 \\
Hepatic abscess & 2 & 6.45 \\
\hline GIT & 12 & 38.70 \\
\hline Adenocarcinoma & & \\
Retroperitoneum & 2 & 6.45 \\
Leiomyosarcoma & 4 & 12.90 \\
\hline Ovary & $\mathbf{3 1}$ & $\mathbf{1 0 0}$ \\
\hline \multicolumn{2}{|c|}{ Total } & \\
\hline \multicolumn{2}{|c|}{ Table 15. Ultrasonography Guided } \\
\hline \multicolumn{2}{|l|}{}
\end{tabular}

\begin{tabular}{|c|c|c|}
\hline Lesions & No. of Lesions & Percentage \\
\hline NILM & 53 & 45.68 \\
\hline ASCUS & 20 & 17.24 \\
\hline LSIL & 25 & 21.55 \\
\hline HSIL & 18 & 15.51 \\
\hline Total & $\mathbf{1 1 6}$ & $\mathbf{1 0 0}$ \\
\hline \multicolumn{2}{|c|}{ Table 16. Pap Smear Cytology- 116 } \\
\hline
\end{tabular}

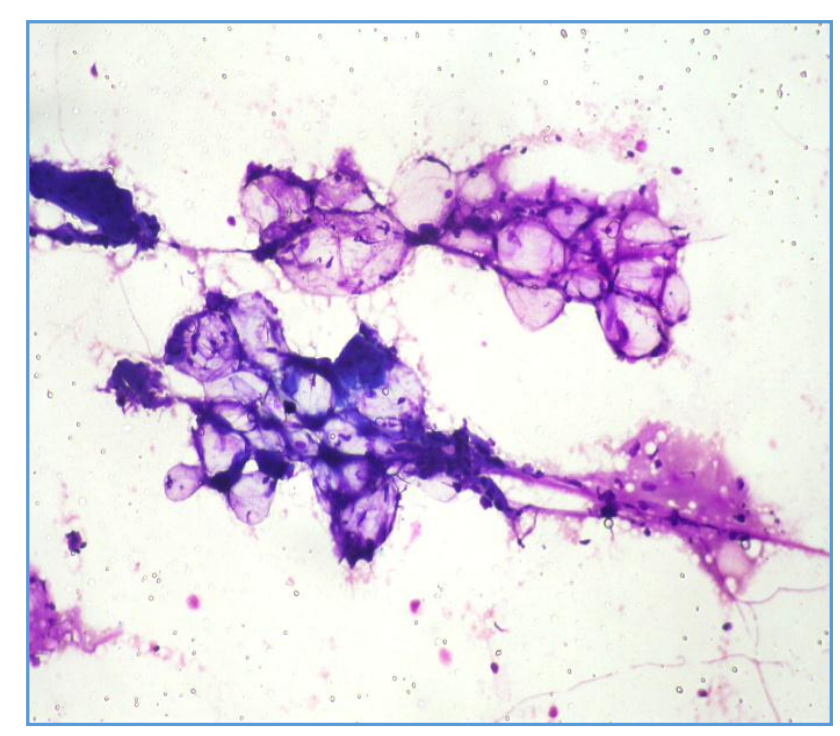

Figure 1. Cytological Diagnosis of Lipoma (H and E, 100X)

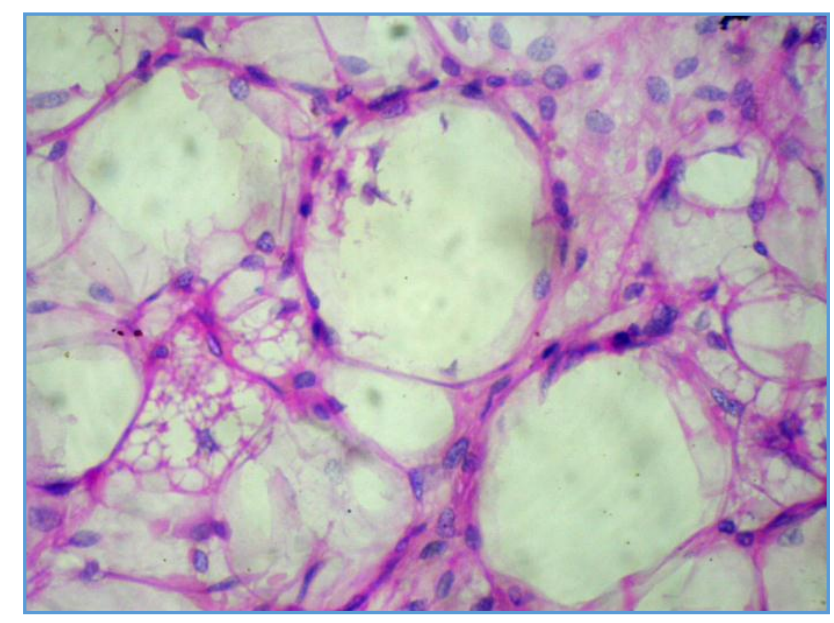

Figure 1A. Histopathological Diagnosis of Atypical Lipoma (H and E, 400X) 


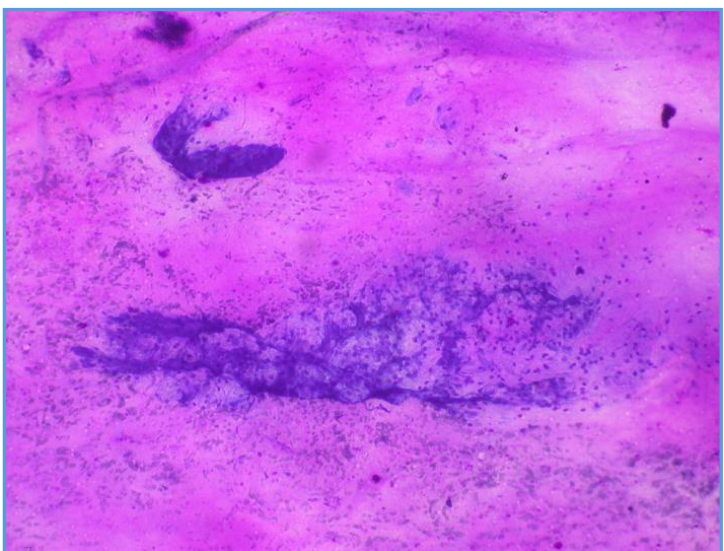

Figure 2. Cytological Diagnosis of Pleomorphic Adenoma (H and E, 100X)

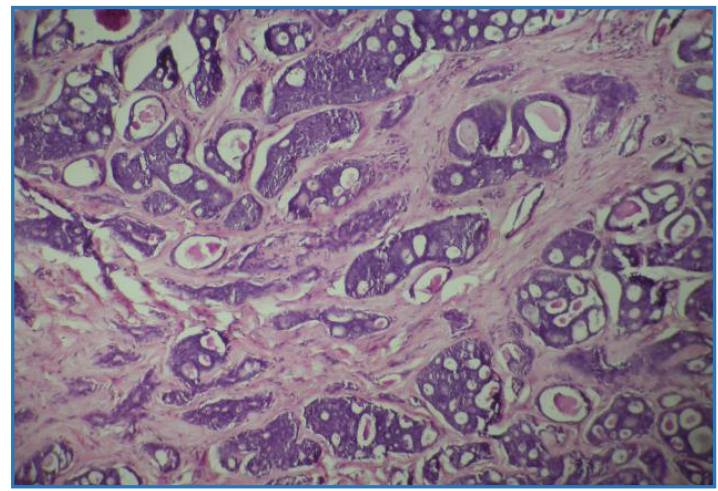

Figure 2A. Histopathological Diagnosis of Adenoid Cystic Carcinoma (H and E, 100X)

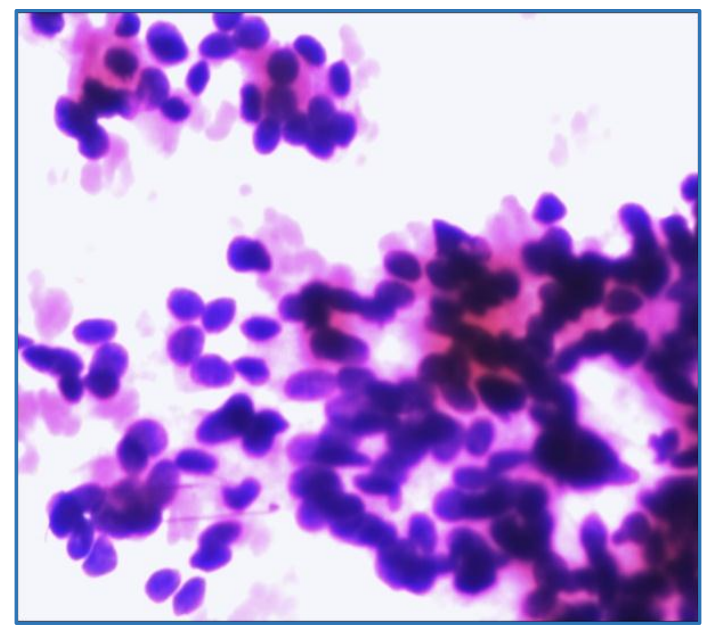

Figure 3. Cytological Diagnosis of Follicular Adenoma (H and E, 400X)

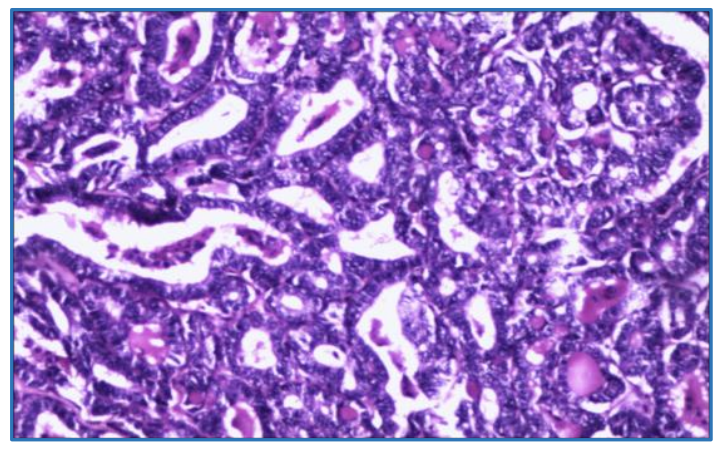

Figure 3A. Histopathological Diagnosis of Follicular Variant of Papillary Carcinoma (H and E, 400X)

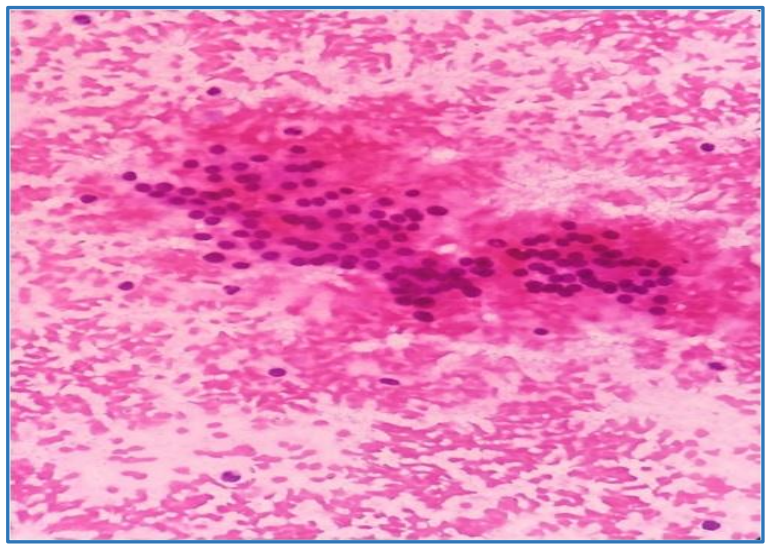

Figure 4. Cytological Diagnosis of Nodular Goitre (H and E, 400X)

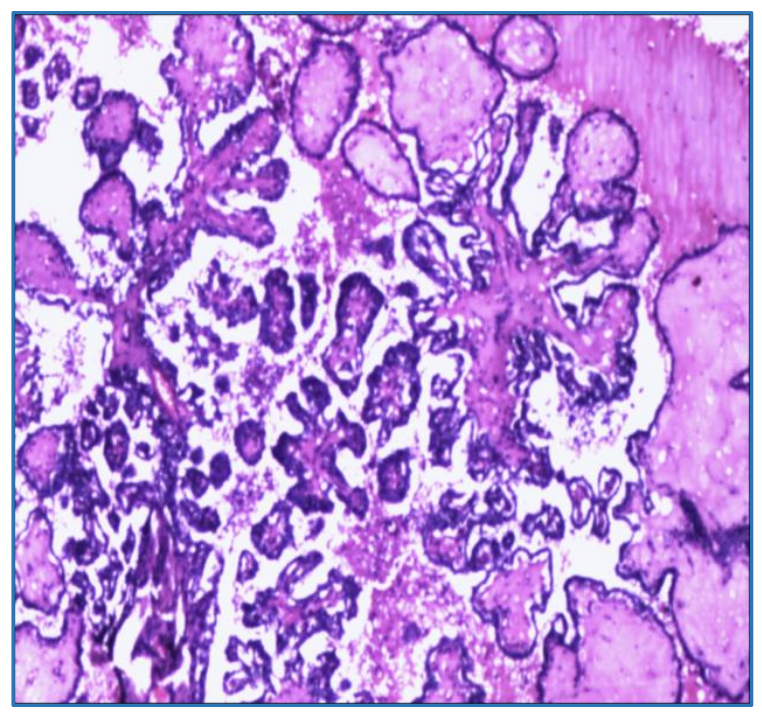

Figure 4A. Histopathological Diagnosis of Papillary Carcinoma (H and E, 400X)

\section{DISCUSSION}

\section{Lymph Nodes}

The main purpose of doing an FNA examination is to decide whether surgical excision is needed in cases of abnormal peripheral lymphadenopathy. Cytological examination can decide whether the lymphadenopathy is due to reactive hyperplasia, metastatic malignancy, granulomatous inflammation and malignant lymphoma. In granulomatous lymphadenitis, the criteria for diagnosis is presence of epithelioid cells, multinucleated giant cells, both foreign body and Langhans giant cell and presence or absence of necrosis. Granulomatous lymphadenitis can be classified as noninfectious and infectious. Non-infectious causes are sarcoidosis and sarcoid-like reaction. Infectious causes can be classified as suppurative and non-suppurative. Suppurative granulomatous disorders include tularaemia, cat scratch disease, and Yersinia. Non-suppurative granulomatous disorders include tuberculosis, tuberculoid leprosy and syphilis.[3] Presence of caseous necrosis with clinical correlation goes in favour of tuberculous lymphadenitis. AFB stain may or may not show bacilli, negative images is sometimes seen. If smears show necrotic debri and plenty of polymorphs with histiocytes, negative AFB stain and culture with clinical diagnosis of tuberculous lymphadenitis poses a challenge to the pathologists. Infection 
with atypical mycobacteria, cat scratch disease, lymphogranuloma venereum and HIV infection has to be considered depending on the site of lymph node involved. Granulomatous inflammation has been associated with metastatic lymphadenopathy and lymphoma. In such cases, interpretation on cytology should be done with great caution.

Sachin A Badge et al,[4] in their study documented tubercular lymphadenitis in $48.70 \%$ of cases. All showed bacilli with ZN stain followed by granulomatous lymphadenitis in $32.90 \%$, reactive hyperplasia in $8.06 \%$ and metastatic carcinoma in $3.87 \%$. The chances of finding AFB are greater when pus or caseous material is aspirated.[5]

Those cases lacking the typical finding and showing scattered epithelioid cells with or without granuloma or only necrotic material with neutrophilic infiltration were diagnosed as tuberculous lymphadenitis, even though AFB was negative in majority of the studies.[6] Excisional biopsy is potentially hazardous, as it gives rise to sinus formation. In developing countries, tuberculous infection is the commonest and even in the absence of typical cytological features trial of antituberculous therapy can be done.[7] In a region where tuberculous infection is common and other granulomatous diseases are rare, the presence of a granulomatous feature in FNAC is highly suggestive of tuberculosis. The literature on the use of FNAC to diagnose tuberculous cervical lesions is mainly from the developing countries, where mycobacterial infections are prevalent.[7]

In the present study analysed 370 cases of lymph node aspiration, 50.81\% were non-specific lymphadenitis, 31.35\% cases were tuberculous lymphadenitis with typical features of caseous necrosis and epithelioid granulomas. Positive bacilli on $\mathrm{ZN}$ stain and on follow-up responded to antituberculous therapy. Nineteen cases of granulomatous lymphadenitis with few epithelioid granulomas, no necrosis and negative for bacilli on ZN stain were subjected for histopathological examination: 7 were due to tuberculous lymphadenitis, 5 cases were due to fungal infection, 5 cases were offered the diagnosis of Hodgkin's lymphoma and 2 cases showed metastatic deposits.

In the study by Sachin A Badge et al,[4] lymph node aspirates (3.87\%) showed metastatic deposits in $3.87 \%$ of cases. In studies by Patel et al and Ghartimagar et al, metastatic deposits were seen in $27.06 \%$ and $18 \%$ of cases

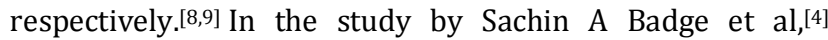
Lymphomas constituted only $0.96 \%$ cases. This was in accordance with the study by Khan et al (2\%).[10] Although, their prevalence is low, they pose a great diagnostic challenge. Age of the patient and polymorphous population of cells and atypical cells should raise a suspicion of Hodgkin's lymphoma. Inadequate samples and fibrosed nodes in advanced disease may be the cause of lack of ReedSternberg cells.

In the present study, metastatic lymphadenitis was seen in $8.37 \%$ of cases and lymphoproliferative disorders in $4.32 \%$ of cases. All the 16 cases with cytological diagnosis of lymphoproliferative disorder was subjected to histopathology and 11 cases turned out to be Hodgkin's lymphoma and 3 cases infectious mononucleosis and 2 cases with diagnosis of Kikuchi's disease with sensitivity of $47.82 \%$, specificity of $58.33 \%$ and diagnostic accuracy of $65.71 \%$.

\section{Breast}

Fine needle aspiration cytology of breast in the hands of experienced cytopathologists have high degree of diagnostic accuracy. ${ }^{[11,12]}$ In the present study for easy interpretation, reporting of breast lesions was divided into 5 -tier system: $\mathrm{C} 1$ for inadequate smears, C2- for benign lesions, C3- suspicious probably benign, C4- suspicious probably malignant and C5malignant breast lesions.

Inadequate smears were not seen in the present study as the aspiration was repeated at least twice, which yielded adequate material for interpretation. C2 category is for smears that are usually cellular showing the characteristic patterns of different benign lesions. No atypical or malignant features are present. Usually duct configurations, myoepithelial cells and bipolar nuclei are visible. Inflammatory background may or may not be seen. In this group the lesions were chronic mastitis (10.96\%), fibroadenosis (20.64\%), fibrocystic disease with nonproliferative epithelium (5.8\%), fibroadenoma (19.35\%), phyllodes tumour $(8.38 \%)$ and gynaecomastia in $7.74 \%$ of cases. The commonly encountered cytological features of fibroadenoma are fibromyxoid stroma, staghorn clusters and numerous single bare nuclei being seen in $90 \%, 78.6 \%$ and $64.6 \%$ of cases, respectively. The absence of any components of the diagnostic triad and low cellularity are the common pitfalls in the diagnosis of fibroadenoma. Similar features were recorded by SM Kollur et al.[13]

Category C3 and C4 are the grey zones. In C3 category benign ductal epithelial cells are seen but with crowding, pleomorphism and discohesion. C4 is reserved for aspirate where atypical features are obvious, but there are features of hypocellularity. Apocrine cells, macrophages and ductal cells are the characteristic features of a non-proliferative type of fibrocystic changes, which yields only scanty materials. Fibrocystic disease of proliferative type, there are sheets and clusters of ductal epithelial cells, presence of atypia in these cellular clusters and nucleoli. Presence of nipple discharge, the diagnosis goes in favour of intraductal papilloma. In the present study, 10/155 (6.45\%) were given the diagnosis of fibrocystic disease with proliferative activity.

C5 category consists of cellular aspirate with evidently malignant cytologic features. It is not always possible to label the exact subtype especially tubular carcinoma, medullary carcinoma and mucinous carcinoma which have excellent prognosis, and usually squamous cell carcinoma and metaplastic carcinoma have bad prognosis. In the present study, carcinoma breast constituted $9.67 \%$ of cases and were diagnosable on FNAC. The type encountered was ductal carcinoma, was NOS type confirmed on histopathology. Sensitivity, specificity and overall diagnostic accuracy of breast lesion was $100 \%, 100 \%$ and $89.47 \%$ respectively.

\section{Thyroid}

FNAC of the thyroid has become increasingly popular as a diagnostic technique as it provides a sensitive, economical method of obtaining cytologic material for examination with distinct advantages which includes accurate diagnosis, excellent patient acceptance and minimal or no morbidity. The sensitivity of the thyroid FNAC ranges from $65 \%$ to $99 \%$ and its specificity from $72 \%$ to $100 \%$.[14] Various studies have shown diagnostic accuracy of $80 \%$ and $100 \%$. Only a small percentage of patients with benign cytological findings 
undergo surgery, it is difficult to know true frequency of false negative results.[15,16]

Pinki Pandey et al[17] in their study documented colloid goitre in $67.94 \%$ cases followed by thyroiditis in $20 \%$ cases, $1.47 \%$ adenomatous goitre and $1.17 \%$ thyroglossal cysts. Among the neoplastic group, 3.52\% cases were reported as follicular neoplasm, $2.05 \%$ cases as Hürthle cell neoplasm and $1.17 \%$ as malignant tumours. FNA revealed a sensitivity of $62.5 \%$, a specificity of $90.74 \%$ and diagnostic accuracy of 82.35\%. Presence of Hürthle cell metaplasia, hyperplastic nodules and papillary hyperplasia were responsible for the false positive diagnoses.

Karen E et al[18] compared Ultrasound-guided sampling of the thyroid and non-aspiration technique of FNA; comparison of these two techniques showed no significant difference with regard to specimen adequacy. No significant difference in diagnostic accuracy was found on comparison of the two techniques.

In the present study, the malignant lesions showed 100\% cytohistopathological correlation. The correlation percentage in cases of nodular goitre was 94\%, 5 cases with longstanding goitre with large size showed foci of papillary carcinoma on histopathology. The correlation percentage is $36.20 \%$ in follicular neoplasm. Out of 58 cases 21 cases were diagnosed as follicular adenoma, 32 were adenomatoid goitre and 5 cases of follicular variant of papillary carcinoma Sensitivity, specificity and overall diagnostic accuracy are $50 \%, 100 \%$ and $75.58 \%$ respectively.

\section{Soft Tissue and Bony Lesions}

FNA biopsies from soft tissue and bone are difficult to interpret as the aspirates have lot of blood or are scanty cellular due to fibrosis. Despite these difficulties, FNA cytology is being used as a diagnostic modality for initial diagnoses, for recurrences and metastases of soft tissue and bone lesions in many centres due to its simplicity, low morbidity, cost-effectiveness and ability to issue rapid diagnoses.[19]

In the study by Arul $\mathrm{P}$ et al[20] the sensitivity, specificity, accuracy of FNAC for diagnosing malignant soft tissue tumours was $91.7 \%, 97.7 \%$ and $97 \%$ respectively. Sensitivity and specificity of soft tissue and bone lesions by FNA in the study by Khalbuss et al[21] was $97 \%$ and $98 \%$ respectively, Kitagawa et al[22] showed $100 \%$ sensitivity and specificity and Hirachand et al[23] showed sensitivity and specificity of $25 \%$ and $100 \%$ respectively. There is wide variation in the sensitivity and specificity of soft tissue and bone lesions, probably due to variable aspirates obtained due to fibrosis and haemorrhage.

In the present study sensitivity, specificity and overall diagnostic accuracy in diagnosing soft tissue tumours on cytology was $46.66 \%, 100 \%$ and $88.67 \%$ respectively. Sensitivity, specificity and overall diagnostic accuracy of cytology in bone and joint lesions were 100\%, 100\% and $86.66 \%$ respectively.

Skin, Salivary Glands, USG-Guided Aspiration of Intraabdominal Lesions and Pap Cytology

In the study by Rajat Gupta et al,[24] the most common lesions were epidermal inclusion cysts $(25.8 \%)$ and ganglions (6.5\%). Among the malignant neoplastic cases, maximum were metastatic deposits of cancer. In USG-guided aspirations, liver was the common site for FNAC in the study done by Tasleem Ahmed et al[25] and Adhikari RC et al.[26] Adenocarcinoma was the most common malignant type in the study made by Shamshad et al.[27]

McGrath et al[28] in his article stated that ASCUS on pap smears has to be differentiated from low-grade SIL (LSIL) and marked reactive changes. High interobserver and intraobserver variability is well documented in the literature on Pap smears regardless of years of training or level of expertise. Tamboli et al[29] documented sensitivity of $90.65 \%$ and diagnostic accuracy of $90.4 \%$ on Pap smears.

In the present study sensitivity, specificity and overall diagnostic accuracy in diagnosing salivary gland lesions is $81.81 \%, \quad 100 \%$ and $88.23 \%$ respectively. Sensitivity, specificity and overall diagnostic accuracy of cytology in USGguided intraabdominal lesions and skin lesions were 100\%. Sensitivity, specificity and overall diagnostic accuracy of cytology on Pap smears were 92.68\%, 93.33\% and 84.48\%.

\section{CONCLUSION}

Cytology Plays a Great Role in Diagnosing Various Lesions but has Limitations. The Lesions in the Grey Zone are-

1. Granulomatous lymphadenitis without caseous necrosis and negative for acid fast bacilli.

2. Lymphoproliferative disorders.

3. Fibrocystic disease of breast of proliferative type.

4. Atypical ductal hyperplasia.

5. Phyllodes tumour of breast.

6. Follicular neoplasm of thyroid.

7. Long-standing large size goitres.

8. Long-standing large size pleomorphic adenoma of salivary gland.

9. Soft tissue tumour, larger than $10 \mathrm{~cm}$.

10. Vascular tumours.

11. ASCUS and HSIL on Pap smears.

All these lesions need histopathological examination to further sub-categorise the lesions.

\section{REFERENCES}

[1] Hajdu SI, Melamed MR. Limitations of aspiration cytology in the diagnosis of primary neoplasms. Acta Cytol 1984;28(3):337-45.

[2] Chan JKC, Tang SK, Tsang WYW, et al. Histologic changes induced by fine-needle aspiration. Advances Anat Pathol 1996;3:71-90.

[3] Khajuria R, Goswami KC, Singh K, et al. Pattern of lymphadenopathy on fine needle aspiration cytology in Jammu. JK Sci 2006;8:157-9.

[4] Badge SA, Ovhal AG, Azad K, et al. Study of fine needle aspiration cytology of lymph node in rural area of Bastar District, Chhattisgarh. Med J DY Patil Univ 2017;10(2):143-8.

[5] Prasoon D. Acid-fast Bacilli in fine needle aspiration smears from tuberculous lymph nodes. Where to look for them. Acta Cytol 2000;44(3):297-300.

[6] Paul PC, Goswami BK, Chakrabarti S, et al. Fine needle aspiration cytology of lymph nodes: an Institutional study of 1448 cases over a five year period. J Cytol 2004;21:187-90. 
[7] Lau SK, Wei WI, Hsu C, et al. Efficacy of fine needle aspiration cytology in the diagnosis of tuberculous cervical lymphadenopathy. J Laryngol Otol 1990;104(1):24-7.

[8] Patel MM, Italiya SL, Dhandha ZB, et al. Study of metastasis in lymph nodes in FNAC: our institutional experience. Int J Res Med Sci 2013;1(4):451-4.

[9] Ghartimagar D, Ghosh A, Ranabhat S, et al. Utility of fine needle aspiration cytology in metastatic lymph nodes. J Pathol Nepal 2011;1:92-5.

[10] Khan AH, Hayat AS, Baloch GH, et al. Study of FNAC in cervical lymphadenopathy. World Appl Sci J 2011;12(11):1951-4.

[11] Bukhari MH, Arshad M, Jamal S, et al. Use of fine needle aspiration in the evaluation of breast lumps. Article ID 689521, Pathology Research International 2011;2011: p. 10.

[12] Panjvani SI, Parikh BJ, Parikh SB, et al. Use of fine needle aspiration cytology in the evaluation of breast lesions. Journal of Clinical and Diagnostic Research 2013;7(12):2777-9.

[13] Kollur SM, El Hag IA. FNA of breast fibroadenoma: observer variability and review of cytomorphology with cytohistological correlation. Cytopathology 2006;17(5):239-44.

[14] Caraway NP, Sneige N, Samaan NA. Diagnostic pitfalls in thyroid fine needle aspiration: a review of 394 cases. Diagn Cytopathol 1993;9(3):345-50.

[15] El Hag IA, Kollur SM, Chiedozi LC. The role of FNA in the initial management of thyroid lesions: 7 year experience in a district general hospital. Cytopathology 2003;14(3):126-30.

[16] Kumori T, Shinya H, Satomi T, et al. Management of nodular goiters and their operative indications. Surg Today 2003;30:722-6.

[17] Pandey P, Dixit A, Chaturvedi V, et al. Usefulness of fine-needle aspiration in the diagnosis of thyroid lesions: an institutional experience of 340 patients. Otolaryngology Online Journal 2013;3(4):1-17.

[18] Schoedel KE, Tubulin ME, Pealer K, et al. Ultrasoundguided biopsy of the thyroid: a comparison of technique with respect to diagnostic accuracy. Diagnostic Cytopathology 2008;36(11):787-9.
[19] Nagira K, Yamamoto T, Akisue T, et al. Reliability of fine-needle aspiration biopsy in the initial diagnosis of soft-tissue lesions. Diagn Cytopathol 2002;27(6):35461.

[20] Arul P, Masilamani S. Fine needle aspiration cytology of soft tissue tumors with its histopathological correlation in a rural hospital of south India: a retrospective study. Clin Cancer Investig J 2016;5(2):146-50.

[21] Khalbuss WE, Teot LA, Monaco SE. Diagnostic accuracy and limitations of fine needle aspiration cytology of bone and soft tissue lesions: a review of 1114 cases with cytological-histological correlation. Cancer Cytopathol 2009;118(1):24-32.

[22] Kitagawa Y, Ito H, Sawaizumi T, et al. Fine needle aspiration cytology for soft tissue tumours of the hand. J Hand Surg Br 2003;28(6):582-5.

[23] Hirachand S, Lakhey M, Singha AK, et al. Fine needle aspiration (FNA) of soft tissue tumours (STT). Kathmandu Univ Med J (KUMJ) 2007;5(3):374-7.

[24] Gupta R, Gupta R, Dewan D, et al. Fine needle aspiration cytology as a diagnostic tool in nodular skin lesions. Int J Med Sci Public Health 2016;5(6):1229-32.

[25] Reyaz TA, Summyia F, Isma N, et al. USG guided fine needle aspiration cytology of intra-abdominal and pelvic masses in Kashmir: a study at tertiary care hospital. International Journal of Medical Research \& Health Sciences 2016;5(4):169-75.

[26] Adhikari RC, Tuladhar A, Shrestha S, et al. Deep-seated thoracic and abdominal lesions: usefulness of ultrasound guided fine needle aspiration cytology, a 3 year experience. Nepal Medical Coll J 2010;12:20-5.

[27] Ahmed SS, Akhtar K, Akhtar SS, et al. Ultrasound guided fine needle aspiration biopsy of abdominal masses. JK Science 2006;8(4):200-4.

[28] McGrath CM. ASCUS in papanicolaou smears. Problems, controversies and potential future directions. Am J Clin Pathol 2002;(Suppl 117):S62-S75.

[29] Tamboli GD. Accuracy of cytological findings in abnormal cervical smear by cyto-histological comparison. Journal of Medical Education \& Research 2013;3(2):19-24. 